\section{Evaluation of Prunus Rootstocks for Root-lesion Nematode Resistance}

\author{
Eduard Alcañiz ${ }^{1}$, Jorge Pinochet ${ }^{2}$, and Carolina Fernández ${ }^{1}$ \\ Departamento de Patología Vegetal, Institut de Recerca i Tecnologia \\ Agroalimentàries, Crta. de Cabrils s/n 08348, Cabrils, Barcelona, Spain
}

Daniel Esmenjaud ${ }^{2}$

Laboratoire de Biologie des Invertébrés, Institut National de la Recherche Agronomique, B.P. 2078, 06606 Antibes Cedex, France

\section{Antonio Felipe ${ }^{3}$ \\ Servicio de Investigación Agraria, Apartado 727, 50080 Zaragoza, Spain}

Additional index words. Pratylenchus vulnus, resistance, rootstocks

\begin{abstract}
Fourteen Prunus rootstocks were evaluated against mixtures of several isolates of the root-lesion nematode Pratylenchus vulnus Allen and Jensen in three greenhouse experiments. Most of the tested rootstocks are new releases or materials in advanced stages of selection that also have incorporated root-knot nematode resistance. The plums Torinel (Prunus domestica L.) and Redglow (P. salicina Lindl. $x$ P. munsoniana Wight and Hedrick cv. Jewel) showed a moderately resistant response; their final nematode population levels were lower or slightly higher than inoculation levels. Low nematode reproduction also was found in the peach-almond hybrid $G \times N$ No $22[P$. persica (L.) Batsch $\times$ P. dulcis (Mill.) D.A. Webb] and the plum Bruce (P. salicina $X$ P. angustifolia Marsh.), and although these rootstocks did not perform as well as Torinel and Redglow, they also appear to be poor hosts for $P$. vulnus.
\end{abstract}

The root-lesion nematode Pratylenchus vulnus is an important pest attacking stone and pome fruit crops in the United States and southern Europe (Fernández et al., 1992; Lamberti, 1981; McElroy, 1972; Scotto la Masesse, 1989). In Spain, Pratylenchus vulnus has been found in nurseries and commercial orchards and has been pathogenic on several Prunus rootstocks (Pinochet et al., 1991, 1993a). This migratory endoparasitic nematode causes the destruction of the root system, which results in loss of vigor and yield in young and mature trees. The economic importance of lesion nematodes in the development of orchard replant problems has been recognized for the last 40 years (Bertrand, 1989; Nyczepir and Halbrendt, 1993). Nematicides and tolerant rootstocks have been the main forms of nematode management (McKenry, 1988). In contrast, breeding for resistance has been one of the most neglected approaches toward achieving effective control of $P$. vulnus in stone fruit rootstocks adapted to warm Mediterranean environments.

Received for publication 5 Feb. 1996. Accepted for publication 30 May 1996. This research was supported by the Spanish Instituto Nacional de Investigaciones Agrarias Grant SC92-132. We thank Agromillora Catalana S.A., Sant Sadurní d'Anoia, Barcelona, and G. Salesses of the Fruit Tree Crop Station, Institut National de la Recherche Agronomique, Bordeaux, France, for providing the plant material. The cost of publishing this paper was defrayed in part by the payment of page charges. Under postal regulations, this paper therefore must be hereby marked advertisement solely to indicate this fact.

${ }^{1}$ Graduate Assistant.

${ }^{2}$ Research Nematologist.

${ }^{3}$ Plant Breeder.
Most of the effort in incorporating host resistance to lesion nematodes in Prunus has been against Pratylenchus penetrans (Cobb) Filipjev and Schuurmans Stekhoven, a rootlesion nematode adapted to temperate environments. Resistance and tolerance for $P$. penetrans has been found in seedlings of the peach rootstock cultivars Rubira, Pisa, Rutgers Red Leaf, Tzim Pee Tao, and in hybrids of Rutgers Red Leaf x Tzim Pee Tao (Layne, 1987; Potter et al., 1984). In contrast, the search for resistance to $P$. vulnus has been less successful, even though potential sources have been detected in Bokhara and Shalil peach seedlings (Okie, 1987) and in a few wild plums, apricots, and interspecific hybrids (Ledbetter, 1994; Scotto La Massese, 1975).

A significant effort in incorporating hostplant resistance is being pursued against this pest in the United States (Ledbetter and Shonnard, 1991), France (Crossa-Raynaud and Audergon, 1987; Stalin et al., 1994), and in Spain (Marull and Pinochet, 1991; Pinochet et al., 1995). In general, resistance has been difficult to find (Ledbetter, 1994) and, even more, to transmit from wild Prunus into commercial rootstocks. Recent findings also indicate the existence of differences in pathogenicity among populations of $P$. vulnus (Pinochet, 1993b, 1994), a consideration that further complicates the evaluation of plant material in the search for resistance and tolerance.

The purpose of this study was to evaluate the host suitability of 14 Prunus rootstocks, some of which (peach and plums mainly) have been resistant (low reproduction) or suspected to be tolerant (nematode reproduces well but plant growth minimally affected) to this nema- tode in the United States, France, Italy, and Spain, to mixtures of several isolates of $P$. vulnus. Nearly all the tested rootstocks have incorporated root-knot nematode resistance (Fernández et al., 1994); some are new cultivar releases or materials in advanced stages of selection.

\section{Materials and Methods}

Inoculum source and preparation. A total of seven $P$. vulnus isolates originating from diverse geographic locations and hosts were obtained from several sources (Table 1). The isolates were reared monoxenically on carrot (Daucus carota L.) disk cultures (Moody et al., 1973) and incubated at $21^{\circ} \mathrm{C}$ for several generations. Species identification was made by the Commonwealth Institute of Parasitology, St. Albans, U. K., or confirmed by PCRRAPD analysis (Pinochet et al., 1994). For inoculation procedures, nematodes from each isolate were recovered from cultures by adding water and collecting the nematode suspension with a pipette. In each experiment, inocula (mixtures of isolates) were adjusted to deliver 600 or 1100 individuals per plant through four holes located at 3 to $4 \mathrm{~cm}$ distance from the base of the plant. Most of the isolates used in this study have proven to be pathogenic on Prunus, Malus, Pyrus, and Cydonia rootstocks.

Plantmaterial. Seeds, herbaceous and hardwood cuttings, and micropropagated material were supplied from sources in Spain, France, and the United States (Table 2). Seeds of the peach rootstock Rutgers Red Leaf were treated with a 5\% solution of copperoxychloride for $24 \mathrm{~h}$, rinsed with running water, covered with moist paper towels, stratified in perlite trays (Europerlite, Dicalite Española S.A., Barcelona, Spain), and kept in a chamber at 4 ${ }^{\circ} \mathrm{C}$ for 45 days. The seeds were then moved to an ambient-temperature greenhouse to induce germination. Buds of Bruce and Redglow were imported to Spain from the IR2/NRSP5 Fruit Tree Collection, Washington State Univ., Prosser. These were grafted on myrobalan plum for wood production (cuttings) the following year. This material, together with herbaceous and hardwood cuttings of the peach Cadaman, peach-almond hybrids $\mathrm{G} \times \mathrm{N}$ No 22 and GF-557, and the plums Montizo and Monpol, was obtained from the Departamento de Fruticultura del Servicio de Investigacion Agraria de la Diputación General de Aragón, Zaragoza, Spain. Cuttings were treated for 10 $\mathrm{s}$ with a $50 \%$ alcohol solution that contained indolebutyric acid at $2000 \mathrm{mg} \cdot \mathrm{L}^{-1}$. Cuttings then were planted in small pots $\left(200 \mathrm{~cm}^{3}\right)$ containing a 3 sand : 1 peat $(\mathrm{v} / \mathrm{v})$ mixture previously pasteurized with steam at $80^{\circ} \mathrm{C}$. Micropropagated peach Barrier and plums AD101, GF-31, Torinel, and Julior were received as plantlets from Agromillora Catalana S.A., Sant Sadurníd' Anoia, Barcelona, Spain. These were transferred from agar to 50-mL minipots with peat substrate and climatized in a highhumidity chamber for 24 days. The micropropagated plum P 2980 was supplied bare root from the Fruit Tree Crop Station of Institut 
Breeding, Cultivars, Rootstocks, \& Germplasm Resources

Table 1. Geographic and host origin of seven isolates of Pratylenchus vulnus used in three experiments.

\begin{tabular}{|c|c|c|c|c|}
\hline Isolate & Geographic origin & Host & Source $^{z}$ & Expt. $^{y}$ \\
\hline$\overline{\mathrm{PvRO}-\mathrm{S}}$ & Barcelona, Spain & Rose (Rosa multiflora Thunb.) & IRTA & $1,2,3$ \\
\hline PvAP-S & Gerona, Spain & Apple (Pyrus malus L.) & IRTA & 1,2 \\
\hline PvPL-S & Alicante, Spain & Plum (Prunus domestica L.) & IRTA & 3 \\
\hline PvAT-F & Antibes, France & Apricot (Prunus armeniaca L.) & INRA & 1,2 \\
\hline PvWA-A & Córdoba, Argentina & Walnut (Juglans nigra L.) & UNC & $1,2,3$ \\
\hline PvAP-U & Idaho, U.S.A. & Apple (Pyrus malus) & UI & 3 \\
\hline PvOL-I & Taranto, Italy & Olive (Olea europea L.) & INA & 1,2 \\
\hline
\end{tabular}

${ }^{2}$ IRTA = Institut de Recerca i Tecnologia Agroalimentàries; INRA = Institut National de la Recherche Agronomique; UNC = Universidad Nacional de Córdoba; UI = Univ. of Idaho; INA = Intituto di Nematologia Agraria.

y Use of isolates in screening Expts. 1,2, and 3.

Table 2. Source of Prunus rootstocks and selections evaluated against Pratylenchus vulnus.

\begin{tabular}{|c|c|c|c|}
\hline Rootstock & Species/selection & Origin $^{z}$ & Expt. \\
\hline Barrier & $\begin{array}{l}\text { Peach }[P \text {. persica }(\mathrm{L}) \text { Batsch } \mathrm{X} \\
P . \text { davidiana (Carr.) Franch.] }\end{array}$ & CNR, Italy & 1,3 \\
\hline Cadaman & Peach $(P$. persica $\times P$. davidiana $)$ & INRA, France & 2 \\
\hline GF-557 & $\begin{array}{l}\text { Peach [P. persica } \mathrm{X} \\
\quad P . \text { dulcis (Mill.) D.A. Webb] }\end{array}$ & INRA, France & 2 \\
\hline Rutgers Red Leaf & Peach $(P$. persica $)$ & Rutgers Univ., U.S.A. & \\
\hline $\mathrm{G} \times \mathrm{N}$ No 22 & $\begin{array}{l}\text { Peach-almond (P. dulcis } \mathrm{X} \\
\text { P. persica) }\end{array}$ & SIA, Spain & 2 \\
\hline AD-101 & Plum (P. insititia L.) & CSIC, Spain & 1 \\
\hline Bruce & $\begin{array}{l}\text { Plum ( } P \text {. salicina Lindl. } \mathrm{x} \\
\text { P. angustifolia } \text { Marsh) }\end{array}$ & $\begin{array}{l}\text { Texas A\&M } \\
\text { Univ., U.S.A. }{ }^{x}\end{array}$ & \\
\hline GF-31 & $\begin{array}{l}\text { Plum (P. cerasifera Ehrh. } \mathrm{x} \\
\quad P \text {. salicina })\end{array}$ & INRA, France & 1 \\
\hline Montizo & Plum $(P$. insititia $)$ & SIA, Spain & 2 \\
\hline Monpol & Plum (P. insititia) & SIA, Spain & \\
\hline P 2980 & Plum $(P$. cerasifera $)$ & INRA, France & 2 \\
\hline Torinel & Plum (P. domestica) & INRA, France & \\
\hline Redglow & $\begin{array}{l}\text { Plum }(P \text {. salicina } \mathrm{x} \\
P . \text { munsoniana Wight and Hedrick })\end{array}$ & $\begin{array}{l}\text { Univ. of Minnesota, } \\
\text { U.S.A. }{ }^{x}\end{array}$ & 3 \\
\hline Julior & Plum $(P$. insititia $\times P$. domestica $)$ & INRA, France & 3 \\
\hline
\end{tabular}

${ }^{2}$ SIA $=$ Servicio de Investigación Agraria; $C N R=$ Consejo Nationale de Recerca; INRA = Institut National de la Recherche Agronomique; CSIC $=$ Consejo Superior de Investigaciones Científicas.

${ }^{y}$ Evaluation of plant material in screening Expts. 1, 2, and 3.

xPlant material was obtained from IR-2, Prosser, Wash.

National de la Recherche Agronomique, Bordeaux, France.

Greenhouse experiments. Two screening experiments lasting 120 days and one screening experiment lasting 110 days were established; the first two were performed in 1994 and the third in 1995. In all the experiments, plant material arising from germinated seeds, rooted cuttings, and micropropagated rootstocks were transplanted to 3-L PVC pots that contained a pasteurized sandy loam soil $(78 \%$ sand, $15 \%$ silt, and $7 \%$ clay), $\mathrm{pH} 7.4,<3 \%$ organic matter content with a cation exchange capacity (CEC) $<12 \mathrm{meq} / 100 \mathrm{~g}$ of soil.

Plants with uniform growth, $\approx 20 \mathrm{~cm}$ tall (10 to 15 leaves), were inoculated with a suspension of 1100 nematodes per plant at 6 weeks after transplanting. To assure a desired pathogenic diversity for testing plant material in both greenhouse screening experiments (Pinochet et al., 1993b), inoculum consisted of a mixture of five $P$. vulnus isolates that included 220 nematodes from each isolate. The $P$. vulnus isolates used in both screening trials were Pv RO-S, Pv AP-S, Pv AT-F, Pv OL-I, and Pv WA-A (Table 1). Inoculated plants were placed in a sand bed to avoid temperature and humidity fluctuations. Each rootstock was replicated eight and 10 times in completely randomized designs in the first and second screening experiment, respectively. Plants were watered as needed and fertilized weekly with tion) in the first and second experiments, as well as with plant material found to be resistant to P. vulnus in the United States and Europe. These evaluated rootstocks were Bruce, Julior, Redglow, and Torinel plums; Rutgers Red Leaf and Barrier peaches; and the peach-almond hybrid G X N No 22. Monpol plum was used as a susceptible control rootstock. Inoculum consisted of a mixture of four P. vulnus isolates ( $\mathrm{Pv} \mathrm{RO}-\mathrm{S}, \mathrm{Pv} \mathrm{PL}-\mathrm{S}, \mathrm{Pv}$ WA$\mathrm{A}$, and Pv AP-U) that included 150 nematodes from each isolate (600 nematodes per plant). Each rootstock was replicated six times in a completely randomized design.

Data on nematode reproduction were analyzed by a one-way analysis of variance. Data were $\log _{10}$ transformed $(x+1)$ for analyses. When $\mathrm{F}$ values were significant, differences between means were evaluated using Fisher's LSD test $(P \leq 0.05)$. Initial population : final population ratios (Pf : Pi) were calculated for each experiment (nematode reproduction rate).

\section{Results}

In the first greenhouse experiment, Barrier, Torinel, and GF-31 had similar final nematode populations (Table 3 ). The nematode count per gram of root in Barrier was significantly lower than that of the other four rootstocks (Table 3). Pratylenchus vulnus multiplication in Monpol was highest, reaching 10,215 nematodes per plant (roots and soil). Torinel, GF-31, and the susceptible AD101 had similar nematode populations, whereas Monpol had the highest nematode density in the roots. Pf : Pi values for Barrier, Torinel, and GF-31 were low compared to values for AD-101 and Monpol.

In the second greenhouse experiment, the final nematode population (roots and soil) was significantly lower in Rutgers Red Leaf, G X N No 22, Bruce, and P 2980 than in Cadaman (Table 4). Rutgers Red Leaf and G x N No 22 differed from Cadaman and Montizo in having fewer nematodes per gram of roots.

The final nematode population for Torinel was significantly lower than for the other rootstocks in Expt. 3 (Table 5). Redglow, G x $\mathrm{N}$ No 22, and Bruce had significantly lower nematode populations than Rutgers Red Leaf, Monpol, Barrier, and Julior. Torinel had the lowest amount of nematodes per gram of root. There were no differences between Redglow, $\mathrm{G} \times \mathrm{N}$ No 22, and Bruce for this characteristic. Barrier differed from Rutgers Red Leaf and Julior but not from Monpol. Rutgers Red Leaf and Julior contained the highest numbers of nematodes per gram of root. Pf: Pi values were lowest for Torinel followed by Redglow, G X N No 22, and Bruce, fluctuating between 0.36 and 1.63. The remaining rootstocks achieved high Pf : Pi values (10.4 to 31.2).

\section{Discussion}

$(100,500$, and 600 mesh, respectively). Root tissue and debris collected on the $150-\mu \mathrm{m}$ sieve were discarded. Nematodes recovered were then counted under a light microscope.

The third experiment was established to confirm results with rootstocks that had shown a resistant response (low nematode reproduc-
Our findings show that GF-557 is a suitable host and likely susceptible. Rutgers Red Leaf peach is susceptible to root-lesion nematode (P. penetrans) infection (Potter et al., 1984). Rutgers Red Leaf, together with Bar- 
Table 3. Reproduction of Pratylenchus vulnus on five Prunus rootstocks 120 days after inoculation with 1100 nematodes per plant in the first greenhouse experiment.

\begin{tabular}{lccc}
\hline \hline & $\begin{array}{c}\text { Final nematode } \\
\text { population } \\
\text { (roots and soil) }\end{array}$ & $\begin{array}{c}\text { Nematodes/ } \\
\text { g of root }\end{array}$ & Pf : $\mathrm{Pi}^{\mathrm{y}}$ \\
\hline Rootstock & $2,166 \mathrm{a}^{\mathrm{x}}$ & $37 \mathrm{a}$ & 1.4 \\
Barrier & $2,285 \mathrm{ab}$ & $144 \mathrm{~b}$ & 2.1 \\
Torinel & $2,492 \mathrm{ab}$ & $102 \mathrm{~b}$ & 2.3 \\
GF-31 & $4,441 \mathrm{~b}$ & $382 \mathrm{~b}$ & 4.0 \\
AD-101 & $10,215 \mathrm{c}$ & $1,975 \mathrm{c}$ & 9.3 \\
Monpol & &
\end{tabular}

${ }^{2}$ Pratylenchus vulnus isolates used in this experiment: $\mathrm{Pv}$ RO-S, Pv AP-S, Pv AT-F, Pv WA-A, and Pv OL-I.

yPf : Pi: final P. vulnus population : initial P. vulnus population (reproduction rate).

${ }^{x}$ Data are means of 10 replications. Actual data are presented, but data were transformed to $\log _{10}(\mathrm{x}+1)$ for analysis. Means in the same columns followed by the same letter do not differ significantly according to Fisher's LSD test $(P \leq 0.05)$.

Table 4. Reproduction of Pratylenchus vulnus on seven Prunus rootstocks 120 days after inoculation with 1100 nematodes per plant in the second greenhouse experiment.

\begin{tabular}{lccc}
\hline \hline & $\begin{array}{c}\text { Final nematode } \\
\text { population }\end{array}$ \\
(roots and soil) & $\begin{array}{c}\text { Nematodes/ } \\
\text { g of root }\end{array}$ & ${\text { Pf : } \mathrm{Pi}^{\mathrm{y}}}^{\mathrm{y}}$ \\
\hline Rootstock & $1,707 \mathrm{a}^{\mathrm{x}}$ & $176 \mathrm{a}$ & 1.6 \\
G X N No 22 & $3,411 \mathrm{a}$ & $326 \mathrm{a}$ & 3.1 \\
Bruce & $3,530 \mathrm{a}$ & $521 \mathrm{ab}$ & 3.2 \\
P-2980 & $3,915 \mathrm{a}$ & $746 \mathrm{ab}$ & 3.6 \\
GF-557 & $6,130 \mathrm{ab}$ & $881 \mathrm{ab}$ & 5.6 \\
Montizo & $10,484 \mathrm{ab}$ & $3,158 \mathrm{~b}$ & 9.5 \\
Cadaman & $18,105 \mathrm{~b}$ & $3,349 \mathrm{~b}$ & 16.5 \\
\hline
\end{tabular}

${ }^{2}$ Pratylenchus vulnus isolates used in this experiment: $\mathrm{Pv}$ RO-S, Pv AP-S, Pv AT-F, Pv WA-A, and Pv OL-I.

yPf : Pi: final $P$. vulnus population : initial P. vulnus population (reproduction rate).

${ }^{x}$ Data are means of eight replications. Actual data are presented, but data were transformed to $\log _{10}(x+1)$ for analysis. Means in the same columns followed by the same letter do not differ significantly according to Fisher's LSD test $(P \leq 0.05)$.

Table 5. Reproduction of Pratylenchus vulnus on eight Prunus rootstocks 110 days after inoculation with 600 nematodes per plant in the third greenhouse experiment.

\begin{tabular}{lccr}
\hline \hline & $\begin{array}{c}\text { Final nematode } \\
\text { population }\end{array}$ & Nematodes/ \\
(roots and soil) & g of root & $\mathrm{Pf} \mathrm{:}^{\mathrm{z}}$ \\
Rootstock & $220 \mathrm{a}^{\mathrm{x}}$ & $18 \mathrm{a}$ & 0.36 \\
\hline Torinel & $580 \mathrm{~b}$ & $70 \mathrm{~b}$ & 0.93 \\
Red Glow & $750 \mathrm{~b}$ & $85 \mathrm{bc}$ & 1.25 \\
G X N No 22 & $980 \mathrm{~b}$ & $110 \mathrm{bc}$ & 1.63 \\
Bruce & $6,290 \mathrm{c}$ & $1,010 \mathrm{ef}$ & 10.48 \\
Rutgers Red Leaf & $6,640 \mathrm{c}$ & $430 \mathrm{de}$ & 11.06 \\
Monpol & $7,110 \mathrm{c}$ & $480 \mathrm{~d}$ & 11.85 \\
Barrier & $18,750 \mathrm{c}$ & $1,630 \mathrm{f}$ & 31.25 \\
Julior & &
\end{tabular}

${ }^{2}$ Pratylenchus vulnus isolates used in this experiment: Pv RO-S, Pv PL-S, Pv Wa-A, and Pv AP-U.

${ }^{y} \mathrm{Pf}$ : Pi: final $P$. vulnus population : initial $P$. vulnus population (reproduction rate).

${ }^{x}$ Data are means of six replications. Actual data are presented, but data were transformed to $\log _{10}(x+1)$ for analysis. Means in the same columns followed by the same letter do not differ significantly according to Fisher's LSD test $(P \leq 0.05)$.

rier, presented an inconsistent response to $P$. vulnus. In the 1994 evaluation trials, both rootstocks achieved a low nematode infection that could be considered as a moderately resistant response. But when tested in the third experiment in 1995, they had a high nematode reproduction, similar to that obtained by the susceptible Monpol plum. However, Torinel, Bruce, and $\mathrm{G} \times \mathrm{N}$ No 22, which had a low nematode reproduction level for $P$. vulnus (Pf : Pi values of 2.1,3.2, and 3.1, respectively) in the screening tests, performed better in the third experiment. Inconsistencies in the evaluation of the same plant material under similar experimental conditions points toward the presence of several nematode isolates in mixtures of the same pathogen. In the third experiment, we used only two of the isolates we had used cause this rootstock was very difficult to propagate, and nearly all plant material died.

Although G x N No 22 and Bruce did not perform as well as Torinel and Redglow, they also appear to be poor hosts for P. vulnus. These four rootstocks represent the most promising plant materials tested so far in Spain where a total of 52 Prunus rootstocks have been evaluated unsuccessfully for resistance and tolerance to $P$. vulnus in the past 5 years (Marull et al., 1990; Marull and Pinochet, 1991; Pinochet et al., 1992, 1993a). GF-31, which performed well in one of the screening trials, was not tested in the third experiment. This rootstock, which is used for apricot cultivars, is tolerant to $P$. vulnus (Crossa-Raynaud and Audergon, 1987).

We conclude that all the evaluated rootstocks show varying degrees of host suitability to the root-lesion nematode. Of these, Torinel, Redglow, G x N No 22, and Bruce have low nematode reproduction. Immunity or a high level of resistance against $P$. vulnus has not been detected. Repeated evaluation is required to verify the results obtained under greenhouse conditions. Because of the good adaptation of Torinel and G x N No 22 to Mediterranean conditions and root-knot nematode resistance (Meloidogyne spp.) (Fernández et al., 1994), both rootstocks should be tested under field conditions in $P$. vulnus-infested soil to determine if the low nematode reproduction we observed is correlated with good vegetative growth and productivity traits in comparison to susceptible rootstocks. Bruce and Redglow would seem to be more valuable in plant breeding, especially in crossings with plum rootstocks that are highly susceptible to $P$. vulnus. The search for sources of resistance in commercial Prunus, or the detection of the trait in wild Prunus species for its incorporation into commercial genotypes, is a priority for rootstocks adapted to Mediterranean environments.

\section{Literature Cited}

Bertrand, P.F. 1989. Peach nematode management in the southeastern United States, p. 751-757. In: N.F. Childers and W.B. Sherman (eds.). The peach. Horticultural Publications, Gainesville, Fla.

Crossa-Raynaud, P. and J.M. Audergon. 1987. Apricot rootstocks, p. 295-320. In: R.C. Rom and R.F. Carlson (eds.). Rootstocks for fruit crops. Wiley, New York.

in the first two screening trials. Host and pathogenic differences among $P$. vulnus populations from different geographic regions have been described (Jensen, 1953; Pinochet et al., 1992, 1993b; Scotto la Massese, 1975) and would seem to complicate any effort in Prunus breeding and selection against this nematode. It is important to use several populations to assure broad resistance.

As difficult as it is to accurately measure plant host resistance against $P$. vulnus, Torinel and Redglow seem to be the only materials tested in this investigation that showed a moderately resistant response. These rootstocks are poor hosts to the nematode as final population levels were lower or slightly higher than inoculation levels. However, Redglow was not tested in the screening trials in 1994 be-
Fernández, C., J. Pinochet, and R. Dolcet. 1992. Host-parasite relationship of Pratylenchus vulnus on apple and pear rootstocks. Nematropica 22:227-236.

Fernández, C., J. Pinochet, D. Esmenjaud, G. Salesses, and A. Felipe. 1994. Resistance among new Prunus rootstocks and selections to rootknot nematodes from Spain and France. HortScience 29:1064-1067.

Hoagland, D. and D.I. Arnon. 1950. The water culture method for growing plants without soil. California Agr. Expt. Sta. Circ. 347. Univ. of California, Berkeley.

Jenkins, W.R. 1964. A rapid centrifugal flotation technique for separating nematodes from soil. Plant Dis. Rptr. 48:692. range studies of two root-lesion nematodes,
Jensen, H. 1953. Experimental greenhouse host 


\section{Breeding, Cultivars, Rootstocks, \& Germplasm Resources}

Pratylenchus vulnus and Pratylenchus penetrans. Plant Dis. Rptr. 37:384-387.

Lamberti, F. 1981. Plant nematode problems in the Mediterranean region. Helm. Abstr., Ser. B, Plant Nematol. Commonwealth Inst. of Helm., St. Albans, Herts, England. 50:145-166.

Layne, R.E. 1987. Peach rootstocks, p. 385-216. In: R.C. Rom and R.F. Carlson (eds.). Rootstocks for fruit crops. Wiley, New York.

Ledbetter, C.L. 1994. Techniques for screening Prunus rootstocks for resistance to Pratylenchus vulnus, p. 34-36. In: A.P. Nyczepir, P.F. Bertrand, and T.G. Beckman (eds.). Stone fruit tree decline. Sixth Workshop Proceedings. New insights and alternative management strategies. Fort Valley, Ga., 26-28 Oct. 1992. U.S. Dept. Agr., Agr. Res. Serv, ARS-122.

Ledbetter, C.L. and R. Shonnard. 1991. Evaluation of Prunus germplasm for resistance to lesion nematode (Pratylenchus vulnus). HortScience 26:709.

Marull, J. and J. Pinochet. 1991. Host suitability of Prunus rootstocks to four Meloidogyne species and Pratylenchus vulnus in Spain. Nematropica 21:185-195.

Marull, J., J. Pinochet, and S. Verdejo. 1990. Respuesta de cinco cultivares de almendro a cuatro especies de nematodos lesionadores en España. Nematropica 20:143-151.

McElroy, F.D. 1972. Nematodes of tree fruits and small fruits, p. 335-376. In: J.M. Webster (ed.). Economic nematology. Academic, London.

McKenry, M.V. 1988. Nematodes, p. 139-147. In: J.H. La Rue and R. Scott Johnson (eds.). Peaches, plums and nectarines. Growing and handling for fresh market. Coop. Ext., Univ. of California, Div. of Agr. and Natural Resources. Publ. 3331.

Moody, E.H., B.F. Lownsbery, and J.M. Ahmed. 1973. Culture of the root-lesion nematode Pratylenchus vulnus on carrot disks. J. Nematol. 5:225-226.

Nyczepir, A.P. and J.M. Halbrendt. 1993. Nematode pests of deciduous fruit and nut trees, $\mathrm{p}$. 381-425. In: K. Evans, D.L. Trudgill, and J.M. Webster (eds.). Plant parasitic nematodes in temperate agriculture. CAB Intl., University Press, Cambridge, U.K.

Okie, W.R. 1987. Plum rootstocks, p. 321-360. In: R.C. Rom and R.F. Carlson (eds.). Rootstocks for fruit crops. Wiley, New York.

Pinochet, J. 1995. La selección de patrones de frutales subtropicales y de clima templado frente a nematodos, p. 331-340. In: Prog. and Proc. Intl. Congr. of Tropical Nematol. XXVII Organization of Nematologists of Tropical America, XIX Sociedad Brasileira de Nematologia. June 1995, Rio Quente, Brazil.

Pinochet, J., L. Cenis, C. Fernández, M. Doucet, and J. Marull. 1994. Reproductive fitness and random amplified polymorphic DNA variation among seven isolatesof the root-lesion nematode Pratylenchus vulnus. J. Nematol. 26:271-277.

Pinochet, J., J. Marull, R. Rodríguez-Kabana, A Felipe, and C. Fernández. 1993a. Pathogenicity of Pratylenchus vulnus on plum rootstocks. Fund. Appl. Nematol. 16:375-380.

Pinochet, J., C. Fernández, D. Esmenjaud, and M. Doucet. 1993b. Effects of six Pratylenchus vulnus isolates on the growth of peach-almond hybrid and apple rootstocks. J. Nematol. 25:843848.

Pinochet, J., S. Verdejo, and J. Marull. 1991. Host suitability of eight Prunus spp. and one Pyrus communis rootstocks to Pratylenchus vulnus, $P$. neglectus and $P$. thornei. J. Nematol. 23:570575.

Pinochet, J., S. Verdejo, A. Soler, and J. Canals. 1992. Host range of the lesion nematode Pratylenchus vulnus in commercial fruit, nut tree, citrus and grape rootstocks in Spain. J. Nematol. 24:693-698.

Potter, J.W., V.A. Dirks, P.W. Johnson, T.H.A. Olthof, R.E.C. Layne, and M.M. McDonnell. 1984. Response of peach seedlings to infection by the root-lesion nematode Pratylenchus penetrans under controlled conditions. J. Nematol. 16:317-322.

Scotto La Massese, C. 1975. Tests d'hôtes de quelques porte-greffe et variétés fruitières à l'égard de Pratylenchus vulnus Allen et Jensen. Comp. Rend. Acad. Agr. France 61:1088-1095.

Scotto La Massese, C. 1989. Les problèmes posés par les nématodes phytophages à l'amandier, $\mathrm{p}$. 33-38. In: A.J. Felipe and R. Socías (eds.). Options méditerranéennes. Séminaire du GREMPA sur les porte-greffe de l'amandier. CIHEAM, Zaragoza.

Stalin, N., D. Esmenjaud, J.C. Minot, R. Voisin, and J. Pinochet. 1994. Comparative host suitability to Meloidogyne spp. and Pratylenchus vulnus in myrobalan plum genotypes (Prunus cerasifera Ehr.). Nematologica 41:344. 